\title{
Correlation between Absolute Neutrophil Count Level and Helicobacter Pylori Infection in Pediatric Gastritis Hotasi Otana Claudia ${ }^{\mathrm{a} *}$, Supriatmo ${ }^{\mathrm{a}}$, Aridamuriany D. Lubis ${ }^{\mathrm{b}}$ \\ *simanjuntakhotasi@yahoo.com
}

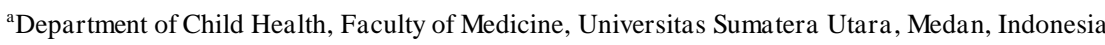
J1. Dr. Mansyur No.5 Padang Bulan, Medan Baru, Medan, North Sumatra 20155, Indonesia ${ }^{\mathrm{b}}$ Faculty of Public Health, Universitas Sumatera Utara, Medan, Indonesia

J1. Dr. Mansyur No.32 Padang Bulan, Medan Baru, Medan, North Sumatra 20155, Indonesia

\begin{abstract}
Helicobacter pylori infection is the most common cause of gastritis worldwide and associated with gastric ulcer and cancer. There are not many studies assessing the significance of baseline and clinical characteristics, and absolute neutrophil count (ANC) in H. pylori associated gastritis. This study assessed the correlation between both baseline and clinical characteristics and ANC in pediatric $\mathrm{H}$. pylori associated gastritis. An analytical cross sectional research was conducted in Haji Adam Malik and Universitas Sumatera Utara hospitals between October - December 2020. Research subjects were pediatric patients with gastritis. They underwent $\mathrm{H}$. pylori screening and ANC test. Independent t-test and Mann-Whitney test were used to assess the correlation. From 82 research subjects, 45 subjects were positive $\mathrm{H}$. pylori and 37 subjects were negative. Demographic data, such as age, gender, ethnicity, socioeconomic status, level of education of children and parents, and parents' occupation, was not significantly correlated to H. pylori infection. Clinical data, such as body height and weight, nutritional status, and symptoms, was not significantly correlated to $\mathrm{H}$. pylori infection. There was no significant difference between ANC and $\mathrm{H}$. pylori infection in the two groups. There were no significant differences in baseline and clinical characteristic data and ANC with pediatric $\mathrm{H}$. pylori gastritis.
\end{abstract}

Keywords: Absolute neutrophil count, Helicobacter pylori, children

\section{Introduction}

Helicobacter pylori (H. pylori) is a gram-negative and motile bacterium that invades the human gastroduodenal mucosa. The microorganism is involved in the development of a number of gastroduodenal diseases, such as chronic gastritis, gastric ulcer, dysplasia or carcinoma, and gastric cancer (Hegar, 2000; Niu et al., 2020). More than half of the world's population is colonized by $\mathrm{H}$. pylori bacteria, where $80 \%$ of infections occurred in developing countries, while $20 \%-50 \%$ in the Western populations (Guclu and Agan, 2017). The prevalence of H. pylori infections varied between adults and children. Also varied based on where they lived, such as low to middle income and industrialized countries. A study in Bangladesh reported $42 \% \mathrm{H}$. pylori prevalence in children aged 2 years old and the rate increased rapidly to $67 \%$ with 10 years old children (Banerjee, 2013). In Jakarta, Indonesia, the prevalence of $\mathrm{H}$. pylori infection was $27 \%$ based on the serological testing done to 150 elementary school students, where $90 \%$ of them were seropositive for H. pylori in their stomaches (Hegar, 2000).

Gastritis is a condition characterized by inflammation, such as in the gastric mucosa, by histological confirmation (Rugge, 2011; Genta, 2003). The main characteristic of H. pylori-induced 
gastritis is the increased infiltration of inflammatory cells, which is also the first characteristic detected in the disease (Niu et al., 2020). H. pylori attract neutrophils and lymphocytes with chemotactic proteins released by the stomach. Substances secreted by mononuclear cells and neutrophils cause mucosal inflammation and gastritis (Guclu and Agan, 2017).

Neutrophils are the first leukocytes to reach inflammation areas and initiate the host's defense mechanism against pathogens. H. pylori chronically infect the stomach and increase neutrophil infiltration to the gastric mucosa. Increased neutrophil count is an important characteristic for inflammation or infection. Therefore, H. pylori infections potentially contribute to neutrophil counts. Absolute neutrophil count (ANC) is the number of immature and mature neutrophils circulating in the peripheral blood (Putra, Siregar, Rey, 2020). Blood cell count or ratio, such as the absolute neutrophil count, is an independent prognostic and predictive marker of some inflammation and infections (Craig et al., 2019). This research assessed how ANC values were related to gastritis in children with and without $\mathrm{H}$. pylori infections. Besides that, demographic and clinical data significance to $\mathrm{H}$. pylori associated gastritis was also assessed.

\section{Methods}

This research used an analytical cross-sectional method to determine the relationship of baseline and clinical characteristic data, as well as ANC values to $\mathrm{H}$. pylori associated gastritis in children. The research was conducted from October-December 2020 at Pediatric Gastroenterohepatology Polyclinic and ward of Haji Adam Malik and Universitas Sumatera Utara hospitals Medan.

Research subjects were children aged 2-18 years old coming to Pediatric Gastroenterohepatology Polyclinic and ward of Haji Adam Malik and Universitas Sumatera Utara hospitals Medan and diagnosed with $\mathrm{H}$. pylori associated gastritis who met the inclusion and exclusion criteria. The research subjects were selected by using consecutive sampling method. The inclusion criteria were children whose parents or guardians agreed to take part in the research by signing the consent form, and children who tested (+) and (-) H. pylori infection for gastritis by endoscopy and CLO. Exclusion criteria were subjects who were under the following drugs for the last 14 days: PPI drugs, H2 blocker antagonists, antibiotics, and NSAIDs, and subjects with other infectious diseases that were non-related to gastritis, other malignancies, immunosuppression, gastrointestinal bleeding, and history of gastrointestinal surgery. There were 82 research samples in the research. Interviews and medical data recording were carried out to obtain baseline and clinical symptoms data of the research subjects. Endoscopic examination and CLO were carried out for H. pylori screening. Blood test was carried out to measure absolute neutrophil count (ANC).

\subsection{Research ethics}

Parents of the research subjects were given explanations about the research and they were asked for consent to be involved in the study. This study was approved by Health Research Ethical Committee, Medical Faculty of Sumatera Utara.

2.2. Data analysis 
Data collected was analyzed by using a computerized software SPSS system version 23. First, categorical data was presented in frequency and percentage. Numerical data was presented as mean \pm standard deviation if the data was normally distributed or median if the data was not normally distributed. Chi-square test was used. Hypothesis test, by using independent t-test, was used to compare two unpaired group (between gastritis groups with and without $\mathrm{H}$. pylori infection) with normal distribution, otherwise Mann-Whitney test was used. Normality test was done by SaphiroWilk. The significance level and confidence interval in this study were $\mathrm{p}<0.05$ and $95 \%$ respectively.

\section{Results}

\subsection{Research subject characteristic and H.pylori infection}

This study was followed by 82 children aged 2-18 years old diagnosed with gastritis at Pediatric Gastroenterohepatology Polyclinic and ward of Haji Adam Malik Hospital and Universitas Sumatera Utara Hospital in Medan, wo met the inclusion and exclusion criteria. The CLO examination found 45 children with gastritis positive $\mathrm{H}$. pylori infection and 37 children without $\mathrm{H}$. pylori infection. Table 1 shows the demographic characteristics of all research subjects.

Table 1. Research subject demographic characteristic

\begin{tabular}{|c|c|c|c|}
\hline \multirow{2}{*}{ Subject Characteristic } & \multicolumn{2}{|c|}{ H. pylori } & \multirow{2}{*}{$\mathbf{P}$} \\
\hline & $(+) n=45$ & $(-) n=37$ & \\
\hline \multicolumn{4}{|l|}{ Gender, n (\%) } \\
\hline Man & $13(28.9)$ & $15(40.5)$ & $0.268^{\mathrm{a}}$ \\
\hline Woman & $32(71.1)$ & $22(59.5)$ & \\
\hline Age, mean (SD), year & $11.79(3.87)$ & $11.99(3.44)$ & $0.819^{\mathrm{b}}$ \\
\hline \multicolumn{4}{|l|}{ Ethnic, n (\%) } \\
\hline Aceh & $6(13.3)$ & $4(10.8)$ & $0.569^{\mathrm{c}}$ \\
\hline Batak & $20(44.4)$ & $14(37.8)$ & \\
\hline India & $1(2.2)$ & 0 & \\
\hline Javanese & $6(13.3)$ & $4(10.8)$ & \\
\hline Malay & $5(11.1)$ & $8(21.6)$ & \\
\hline Mining & $4(8.9)$ & $4(10.8)$ & \\
\hline Papua & $2(4.4)$ & 0 & \\
\hline Chinese & $1(2.2)$ & $3(8.1)$ & \\
\hline \multicolumn{4}{|l|}{ Social-economic, n (\%) } \\
\hline Poor & $7(15.6)$ & $4(10.8)$ & $0.746^{\mathrm{d}}$ \\
\hline Good & $38(84.4)$ & $33(89.2)$ & \\
\hline \multicolumn{4}{|l|}{ Children Education, n (\%) } \\
\hline Kindergarten & $2(4.4)$ & $3(8.1)$ & $0.913^{\mathrm{c}}$ \\
\hline Elementary School & $18(40)$ & $12(32.4)$ & \\
\hline Junior High school & $11(24.4)$ & $11(29.7)$ & \\
\hline Senior High School & $10(22.2)$ & $8(21.6)$ & \\
\hline
\end{tabular}




\begin{tabular}{|c|c|c|c|}
\hline University & $4(8.9)$ & $3(8.1)$ & \\
\hline \multicolumn{4}{|l|}{ Father's Education, n (\%) } \\
\hline Senior High School & $8(17.8)$ & 7 (18.9) & $0.894^{\mathrm{a}}$ \\
\hline University & $37(82.2)$ & $30(81.1)$ & \\
\hline \multicolumn{4}{|l|}{ Mother's Education, n (\%) } \\
\hline Senior High School & $5(11.1)$ & $2(5.4)$ & $0.449^{d}$ \\
\hline University & $40(88.9)$ & $35(4.6)$ & \\
\hline \multicolumn{4}{|l|}{ Father's occupation, n (\%) } \\
\hline Employees & $21(46.7)$ & $20(54.1)$ & $0.816^{\mathrm{c}}$ \\
\hline Farmer & $4(8.9)$ & $1(2.7)$ & \\
\hline Government employees & $6(13.3)$ & $5(13.5)$ & \\
\hline Police & $2(4.4)$ & $2(5.4)$ & \\
\hline Businessman & $12(26.7)$ & $2(5.4)$ & \\
\hline \multicolumn{4}{|l|}{ Mother's occupation, n (\%) } \\
\hline Employees & $14(31.1)$ & $16(43.2)$ & $0.237^{\mathrm{c}}$ \\
\hline Farmer & $6(13.3)$ & $1(2.7)$ & \\
\hline Government employees & $10(22.2)$ & $4(10.8)$ & \\
\hline Businesswoman & $9(20)$ & $10(27)$ & \\
\hline Housewife & $6(13.3)$ & $6(16.2)$ & \\
\hline
\end{tabular}

${ }^{\mathrm{a} C h i}$ square, ${ }^{\mathrm{b}}$ Mann Whitney, ${ }^{\mathrm{c}}$ Kruskal Wallis, ${ }^{\mathrm{d}}$ Fischer's Exact

From 45 gastritis cases with $\mathrm{H}$. pylori infection, 32 children $(71.1 \%)$ were female, whereas in 37 gastritis cases without $\mathrm{H}$. pylori infection, 22 children (59.5\%) were male. Using the Chi Square test, there was no difference in the proportion of genders in the two study groups $(p=0.268)$. The mean age of children with gastritis with and without $\mathrm{H}$. pylori infection was 11.79 years old and 11.99 years old respectively. There was no significant age difference $(p=0.819)$ between the two study groups after the analysis by using Mann-Whitney test.

Based on ethnicity, Batak tribe was dominant in the two groups, where there were 20 children (44.4\%) in the group with H. pylori infection and 14 children (37.8\%) in the group without H. pylori infection. By Kruskal Wallis test, there were no differences in the proportion of ethnic groups $(\mathrm{p}=0.569)$ in the two study groups. Good socio-economic level was dominant in the two groups, where there were 38 children (84.4\%) in the group with H. pylori infection and 33 children (89.2\%) in the group without $\mathrm{H}$. pylori infections having good socio-economic status. Using Fischer's exact test, there was no difference in socio-economic status in the two study groups ( $\mathrm{p}=$ 0.746). As for children's education levels, there were 18 children $(40 \%)$ in primary level from the group with $\mathrm{H}$. pylori infection and 12 children $(32.4 \%)$ in primary level from the group without $\mathrm{H}$. pylori infection. There was no significant difference in the educational level of children in the two study groups $(\mathrm{p}=0.913)$ after the analysis by Kruskal Wallis test. As for the parents, all of the parents of the research subjects had high education (high school and university graduates). There was no significant difference in the education level of the subjects' father and mother in the two study groups ( $p>0.05)$. The majority of parents were working as employees. There was no significant difference in the type of work of the father and mother of the subjects in the two study 
groups $(\mathrm{p}>0.05)$.

\subsection{Research subjects clinical characteristic and H.pylori infection}

Table 2 shows clinical characteristics of the study subjects. The mean body weight and height in children with $\mathrm{H}$. pylori infection were $37.89 \mathrm{~kg}$ and $137.89 \mathrm{~cm}$ respectively. Whereas, the mean weight and height in the group of children without $\mathrm{H}$. pylori infection were $36 \mathrm{~kg}$ and $137 \mathrm{~cm}$ respectively. There was no difference in mean weight and height between the two groups ( $>>0.05)$. Based on the assessment of nutritional status, most research subjects had good nutritional status, where 33 children $(73.3 \%)$ were from the group with $\mathrm{H}$. pylori infection and 29 children $(78.4 \%)$ were from the group without $\mathrm{H}$. pylori infection. There was no difference in nutritional status between the two groups $(\mathrm{p}=0.411)$.

Abdominal pain was the most found symptom in the children with $\mathrm{H}$. pylori infection (54.2\%). Similarly, 22 children $(59.5 \%)$ without $\mathrm{H}$. pylori infection also complained about abdominal pain There was no significant difference in clinical symptoms between the two study groups $(\mathrm{p}=0.320)$.

Table 2. Clinical characteristic of research subjects

\begin{tabular}{|c|c|c|c|}
\hline \multirow{2}{*}{ Clinical Characteristics } & \multicolumn{2}{|c|}{ H. pylori } & \multirow{2}{*}{$\mathbf{F}$} \\
\hline & $(+) n=45$ & $(-) n=37$ & \\
\hline Weight, mean (SD), kg & $37.89(15.67)$ & $36.84(11.51)$ & $0.735^{\mathrm{a}}$ \\
\hline Height, mean (SD), cm & $137.89(20.59)$ & $137.68(16.73)$ & $0.856^{\mathrm{b}}$ \\
\hline \multicolumn{4}{|l|}{ Nutritional Status, n (\%) } \\
\hline Poor & $1(2.2)$ & $1(2.7)$ & $0.411^{\mathrm{c}}$ \\
\hline $\mathrm{Bad}$ & $6(13.3)$ & $2(5.4)$ & \\
\hline Good & $33(73.3)$ & $29(78.4)$ & \\
\hline Over weight & $3(6.7)$ & $5(13.5)$ & \\
\hline Obesity & $2(4.4)$ & 0 & \\
\hline \multicolumn{4}{|l|}{ Clinical Sign, n (\%) } \\
\hline Nausea & $1(2.2)$ & $3(8.1)$ & $0.320^{\mathrm{c}}$ \\
\hline Vomit & $12(26.7)$ & $5(13.5)$ & \\
\hline Blood Vomit & $6(13.3)$ & $7(18.9)$ & \\
\hline Abdominal Pain & $26(54.2)$ & $22(59.5)$ & \\
\hline
\end{tabular}

a T-Independent, ${ }^{\mathrm{b} M a n n}$ Whitney, ${ }^{\mathrm{c} K r u s k a l}$ Wallis

3.3. ANC value in pediatric gastritis with and without H.pylori infection

Absolute neutrophil count (ANC) value in children with $\mathrm{H}$. pylori infection group was $4.55 \mathrm{x}$ $103 / \mu \mathrm{L}(\mathrm{SD}=1.5 \times 103 / \mu \mathrm{L})$, while the mean ANC value in the group of children with gastritis without $\mathrm{H}$. pylori infection was $4.43 \times 103 / \mu \mathrm{L}(\mathrm{SD}=1.95 \times 103 / \mu \mathrm{L})$. Using Mann-Whitney test, there was no significant difference in the mean ANC between the two study groups $(p=0.290)$. The data is shown in Table 3.

Table 3. ANC value and H.pylori infection 


\begin{tabular}{|c|c|c|c|}
\hline \multirow{2}{*}{ ANC Value } & \multicolumn{2}{|c|}{ H. pylori } & \multirow{2}{*}{$\mathbf{P}^{\mathbf{a}}$} \\
\hline & $(+) n=45$ & $(-) n=37$ & \\
\hline \multicolumn{4}{|l|}{$\mathrm{ANC}, \times 10^{3} / \mu L$} \\
\hline Mean & 4.55 & 4.43 & 0.290 \\
\hline Median & 4.38 & 3.68 & \\
\hline SD & 1.50 & 1.95 & \\
\hline $\operatorname{Min}-\max$ & $2.36-9.24$ & $2.44-9.69$ & \\
\hline
\end{tabular}

\section{Discussion}

\subsection{Research subject characteristic and H.pylori infection}

From the basic characteristic data of research subjects, there were no significant relationships in basic characteristic data between gastritis patients with and without $\mathrm{H}$. pylori infection. From gender aspect $(\mathrm{p}=0.268)$, but there were more female patients than male patients in both groups. A retrospective study to 248 children between $0-18$ years old, reported $30.2 \% \mathrm{H}$. pylori infection in male, and $69.8 \% \mathrm{H}$. pylori infection in female. Meanwhile, there were $36.1 \%$ male and $63.9 \%$ female gastritis patients without $\mathrm{H}$. pylori infections. There was, however, no significant relationship between gender and $\mathrm{H}$. pylori infection ( $\mathrm{p}=0.43$ ) (Alimohammadi et al., 2016). Similarly, the study done by Ozen et al reported no statistical significance between gender and $\mathrm{H}$. pylori infection, however, female tended to experienced $\mathrm{H}$. pylori infection than male $(\mathrm{p}=0.8)$ (Ozen et al., 2011). This was assumed to be related to hormonal differences between male and female and the role of oxytocin in gastric evacuation (Fiedorek et al., 1991).

The average age of research subjects in this research was11.79 and 11.99 years old in positive and negative $H$. pylori infection groups. There was no significant relationship $(\mathrm{p}=0.819)$ between age and H. pylori infection. However, the study by Alimohammadi et al., (2016) reported that the prevalence of $\mathrm{H}$. pylori infection increased with the increase in age $(\mathrm{p}<0.05)$ (Alimohammadi et al., 2016). Fiedorek et al reported the increase in H. pylori infection from $24 \%$ to $45 \%$ with the increase in age from $3-5$ years old to $16-20$ years old (Fiedorek et al., 1991). Regarding the level of education of research subjects, most subjects were in secondary and high school level. There was no significant relationship $(\mathrm{p}=0.913)$ between subjects' level of education and $\mathrm{H}$. pylori infection.

Higher prevalence of $\mathrm{H}$. pylori infection may be found in certain ethnicity. Theoretically, it was correlated with migration theory, that one ethnicity from higher prevalence area may inherit $\mathrm{H}$. pylori infection to where they migrated. Genetic factors can play a role in the high incidence of $\mathrm{H}$. pylori infection (Fiedorek et al., 1991).In this study however, there was no significant relationship $(\mathrm{p}=0.569)$ found between ethnicity and H.pylori infection.

The study done by Hasonah et al in Saudi Arabia reported a significant relationship between socioeconomic status and $\mathrm{H}$. pylori infection $(\mathrm{p}=0.016)$, where there were higher cases of $\mathrm{H}$. pylori infection in subjects with low socioeconomic status (Hasonah et al., (2014). A different study conducted in Taiwan, there were $84.4 \%$ subjects with good socioeconomic status and they reported no significant relationship between socioeconomic status and $\mathrm{H}$. pylori infection $(\mathrm{p}=0.473$ ) (Chen et al., 
2014). Similarly in this study, there was no significant relationship between socioeconomic status and $\mathrm{H}$. pylori infection cases $(\mathrm{p}=0.746)$. Most of the parents of the research subjects were high school and university graduates. Most of them also work as employees in companies, hence providing good socioeconomic status. The study done in the Unites States showed that high rate of $\mathrm{H}$. pylori infection was correlated with low level of education, which related to socioeconomic status, low sanitation, and high population density. Such conditions led to close contact between individuals and allowed diseases to transmit easily (Fiedorek et al., 1991).

\subsection{Research subjects clinical characteristic and H.pylori infection}

Clinical characteristics and their relationships to H. pylori infection assessed in this study were body height and weight, nutritional status and clinical symptoms. There were no significant relationships found among these characteristics with $\mathrm{H}$. pylori infection. The study done by Chen et al in Taiwan reported no significant relationship of body weight and height with $\mathrm{H}$. pylori infection, where $p=0.847$ and $p=0.132$ respectively (Chen et al., 2014). Mahalanabis et al previously reported that $H$. pylori infection was not correlated with nutritional status based on body weight and age (Mahalanabis et al., 1996). While, there was a study in China done by Xu et al reported that obese adult patients were more likely to have $\mathrm{H}$. pylori infection than patients with normal nutritional status or overweight (Xu et al., 2019). The mechanism underlying this finding was uncertain but it was suspected that the gastrointestinal hormones, ghrelin and leptin, were involved in metabolic control and energy balance. Ghrelin is produced in the stomach and stimulated food intake, while leptin has the opposite effect. Studies reported lower leptin and ghrelin serum levels in patients with H. pylori infection. Leptin decreased appetite, so the decrease in leptin led to increased food intake and obesity. Meanwhile, decreased ghrelin serum levels led to physiological adaptations of energy balance and was associated with obesity (Xu et al., 2019).

As for the clinical symptoms, abdominal pain was the most commonly found complaint, where over half research subjects with and without $\mathrm{H}$. pylori infection complained about abdominal pain. Other clinical symptoms, such as nausea was found after vomiting and vomiting blood. However, there was no significant relationship between clinical symptoms, i.e. abdominal pain, vomiting, vomiting blood, and nausea, with H. pylori infection $(p=0.320)$. The results of this study were aligned with previous study that stated no specific symptoms for H. pylori infection, as the gastrointestinal symptoms were similar between positive and negative $\mathrm{H}$. pylori infection cases. There was no significant relationship reported between $\mathrm{H}$. pylori associated gastritis with clinical symptoms, such as vomiting, vomiting blood, nausea, and abdominal pain $(p=0.32)$ (Tina, Dwi, and Herry, 2013).

\subsection{ANC value in pediatric gastritis with and without H.pylori infection}

A study in Iran by Jafarzadeh et al reported higher neutrophil count $\left(>7000\right.$ cells $\left./ \mathrm{mm}^{3}\right)$ in patients with peptic ulcer and $\mathrm{H}$. pylori infection than patients with $\mathrm{H}$. pylori asymptomatic infection and control group $\left(\left(>5500\right.\right.$ cells $\left./ \mathrm{mm}^{3}\right)$. A significant relationship $(\mathrm{p}<0.001)$ between neutrophil count and H. pylori infection peptic ulcer was reported (Jafarzadeh et al., 2013). The formation of higher leukocyte cells and neutrophils was reinforced by proinflammatory cytokines, like tumor necrosis factor (TNF), IL-1, and IL-6 for examples. The increase in TNF, IL-1, IL-6 and IL-8 was found in subjects with H. pylori infections. These cytokines could increase white blood 
cells differential count during H. pylori infection. Proinflammatory cytokine IL-17A was also known to increase neutrophil count by inducing G-SCF. Moreover, neutrophil activating protein of Helicobacter pylori (HP-NAP) was known to increase neutrophil lifespan (Jafarzadeh et al., 2013). However, there was no significant relationship between absolute neutrophil count (ANC) and $\mathrm{H}$. pylori infection.

The study in Romania, by Sasaran et al done to 151 children aged $1-17$ years old, divided all research subjects into 3 groups, such as 31 children with $\mathrm{H}$. pylori infection gastritis, 53 children with negative $\mathrm{H}$. pylori gastritis, and 67 children in control group. The research was done to evaluate the effect of gastritis in children with and without $\mathrm{H}$. pylori infection and the hematological parameters. The number of neutrophil count in $\mathrm{H}$. pylori associated gastritis was $3923 \pm 1747$ / $\mu \mathrm{L}$, while the group without $\mathrm{H}$. pylori infection had neutrophil count of $4077 \pm 1494 / \mu \mathrm{L}$. There was no significant relationship between neutrophil counts and $\mathrm{H}$. pylori associated gastritis in all children $(p=0.332)$ in the three groups (Sasaran et al., 2020). Similarly, Sahin, Gubur, and Tekingunduz reported no significance $(p=0.452)$ between neutrophil count and $\mathrm{H}$. pylori gastritis in their research with $153 \mathrm{H}$. pylori infected children and 211 negative H. pylori infection (Sahin, Gubur, and Tekingunduz, 2020). Nonetheless, neutrophil count still needs to be monitored during and after H. pylori infection treatment to improve prognostic and predictive values (Jafarzadeh et al., 2013).

\section{Conclusion}

There were no significant differences in baseline and clinical characteristic data and ANC with pediatric $\mathrm{H}$. pylori gastritis.

\section{References}

Alimohammadi H, Fouladi N, Salehzadeh F, Alipour SA, Javadi MS. Childhood recurrent abdominal pain and Helicobacter pylori infection, Islamic Republic of Iran. EMHJ. 2016; 22(12):860-64.

Banerjee A, Mukhopadhyay AK, Paul S, Bhattacharyya A, Swarnakar S. Unveiling the intricacies of Helicobacter pyloriinduced gastric inflammation. In: Mozsik G, editor. Current Topics in Gastritis. Croatia: InTech Publishers; 2013.

Chen H, Chen M, Shih S, Wang H, Lin I, Bair M. Socioeconomic status, personal habits, and prevalence of Helicobacter pylori infection in the inhabitants of Lanyu. Journal of the Formosan Medical Association. 2014; 113:278-83.

Craig A, Mai J, Cai S, Jeyaseelan S. Neutrophil recruitment to the lungs during bacterial pneumonia. American Society for Microbiology. NCBI. 2009

Fiedorek S, Malaty HM, Evans DL, Pumphrey CL, Casteel HB, Evans DJ. Factors influencing the epidemiology of Helicobacter pylori infection in children. Pediatrics. 1991; 88(3):578-82.

Genta GM. Yamada's Textbook of Gastroenterology.4th edition. Yamada T. Lippincolt William \& Wilkins Publishers. 2003.

Guclu M, Agan AF. Association of severity of Helicobacter pylori infection with peripheral blood neutrophil to lymphocyte ratio and mean platelet volume. Euroasian Journal of Hepato-Gastroenterology. 2017; 7(1):11-6.

Hasosah M, Satti M, Shehzad A, Alsahafi A, Sukkar G, Alzaben A, et al. Prevalence and risk factors of Helicobacter pylori infection in Saudi children: A three-year prospective controlled study. John Wiley \& Sons Ltd, Helicobacter. 2014; 20:56-63.

Hegar B. Infeksi Helicobacter pylori pada anak. Sari Pediatri. 2000; 2(2):82-9.

Jafarzadeh A, Akbarpoor V, Nabizadeh M, Nemati M, Rezayati MT. Total leukocyte counts and neutrophil-lymphocyte count ratios among Helicobacter pylori-infected patients with peptic ulcers: independent of bacterial CagA status. Southeast Asian Journal of Tropical Medicine \& Public Health. 2013; 44(1):82-8.

Mahalanabis D, Rahman MM, Sarker SA, Bardhan PK, Hildebrand P, Beglinger C et al. Helicobacter pylori infection in the young in Bangladesh: prevalence, socioeconomic and nutritional aspects. Int J Epidemiol. 1996; 25:894-8.

Niu Q, Zhu J, Yu X, Feng T, Ji H, Li Y, et al. Immune response in H. pylori- associated gastritis and gastric cancer. Gastroenterology Research and Practice. 2020. 
Ozen H, Dinler G, Akyon Y, Kocak N, Yuce A, Gurakan F. Helicobacter pylori infection and recurrent abdominal pain in Turkish Children. Blackwell Science. 2001; 6:234-38.

Putra AR, Siregar GA, Rey I. Difference between Hsp60 in positive and negative H. pylori gastritis patients and its correlation with neutrophil and lymphocyte ratio. International Journal of Research Science \& Management. 2020; 7(1):62-7.

Rugge M, Pennelli G, Pilozzi E, Fassan M, Ingravallo G, Russo VM, et al. Gastritis: The histology report. Dig Liver Dis. 2011; 43 Suppl 4:S373-84

Sahin Y, Gubur O, Tekingunduz E. Relationship between the severity of Helicobacter pylori infection and neutrophil and lymphocyte ratio and mean platelet volume in children. Arch Argen Pediatr. 2020; 118(3):e241-45.

Sasaran MO, Melit LO, Mocan S, Ghiga DV, Dobru ED. Pediatric gastritis and its impact on hematologic parameters. Medicine. 2020; 99:35(e21985).

Tina R,Dwi P,Herry G. Efektivitas terapi infeksi Helicobacer pylori pada anak dengan keluhan sakit perut berulang setelah satu tahun terapi eradikasi. Sari Pediatri. 2013; 15:111-15.

Xu X, Li W, Qin L, Yang W, Yu G, Wei Q. relationship between Helicobacter pylori infection and obesity in Chinese adults: A systematic review with meta-analysis. PloS One. 2019; 14(9):e0221076. 